\title{
Opportunities and challenges of using social media communication in patient care and counselling in family practice: a scoping review and ethical analysis.
}

Daniel Kabonge Kaye ( $\nabla$ dankkaye@yahoo.com )

Research article

Keywords: Social media; WhatsApp; Facebook; Patient care; Health Professional education; Ethical Issues

Posted Date: September 24th, 2019

DOI: https://doi.org/10.21203/rs.2.14884/v1

License: (9) (1) This work is licensed under a Creative Commons Attribution 4.0 International License.

Read Full License 


\section{Abstract}

Background Healthcare professionals frequently use social media in interacting with colleagues or patients. The aim of this review is to provide a conceptual analysis of ethical issues related to utilization of social media in patient care and health professional training.Methods Using a scoping review, electronic databases (PubMed, HINARI, Google Scholar and ERIC) were searched for publications on use of social media (especially Facebook and WhatsApp) during patient care. Challenges and opportunities faced by users (patients, educators and healthcare professionals) were analyzed.Results Communication between patients and healthcare professionals using WhatsApp and Facebook can improve patient care through improving patients' understanding of and coping with their illness in family practice. It may also improve the learning environment, increase learning opportunities, complement the teaching/learning process, and enhance professional networking and performance. This presents potential risks and burdens to all related to the technology, user behaviors and nature of interactions. The ethical challenges affect data quality, security and effectiveness of the media.Conclusion Users of WhatsApp and Facebook for communication of educational or patient care-related matters should recognize ethical challenges related to using these media platforms in family practice. User preferences for exchange of medical carerelated information or educational material should be sought and respected.

\section{Background}

Social media tools include Facebook, Instagram, WhatsApp, Twitter, LinkedIn, and video-hosting sites like YouTube [1-4]. Healthcare professionals and medical students frequently make use of social media in communicating, learning or interacting with colleagues or patients $[2,5,6]$. Since these platforms provide tools where users exchange conversation, comment, deliberate, critique, contribute, share, create, modify and evaluate contents online, their potential uses are enormous [2-7]. They present a personal learning environment for students $[2,3,8,9]$, a forum for communication between patients and healthcare professionals $[10,11]$, and a medium for communication between healthcare professionals $[12,13]$. While offering great potential to improve patient care, the use presents potential risks to patients and health workers that relate to the technology and the users, include distribution of poor-quality information [1319]. The aim of this review is to provide a conceptual analysis of ethical issues related to utilization of social media and media applications in improving healthcare patient care.

\section{Methods}

Using a scoping review design informed by Arksey \& O’Malley [20], relevant electronic databases (PubMed, HINARI, Google Scholar and ERIC (up to October, 2018) were searched for publications on use of social media digital platforms in general and WhatsApp in particular for challenges and opportunities faced by the users as a community of practice, who use then to communicate patient-related information. Search terms used included Social media, digital platforms, Facebook and WhatsApp. Both peer-reviewed and non-peer reviewed published articles, published in English were selected. During analysis, ethicsrelated considerations related to benefits, risks and burdens were identified, analyzed using the 
framework for Communities of Practice [22,23], Bandura's Social Cognitive Theory [24,25], and Jonas' theory of responsibility [21]. The data were grouped into themes and sub-themes following an inductive qualitative approach [20], with the ethics domains constituting the themes and the specific challenges constituting the sub-themes.

\section{Theoretical framework: Jonas' theory of responsibility}

Jonas [21] developed a theory of ethics applicable to the technological age. Modern technology has potential to generate new threats which are inseparably linked with the technology [21]. Agents are accountable irrespective of the intentions of the action, and accountability may be at individual or collective level [21], and as an imperative of responsibility, humans as rational agents ought to minimize risks and burdens imposed by technology [21].

\section{Results}

Social media (such as WhatsApp and Facebook) presents an effective learning and teaching environment, as they can be adapted to the internet [26-28], offering invaluable opportunities for patient education and counselling $[2,29]$ as well as for social, participatory and collaborative learning [31-34]. While social may create ethical issues related to loss of autonomy, inequitable access, risks such as loss of data security, or unfair distribution of risks and benefits, classifiable into four categories: Beneficence (maximizing benefit and minimizing harms), Autonomy (respect for individuals and communities of users) and justice (treating people equally and fairly. Whats App and Facebook communication have potential to improve patient-physician interactions, enhance patient motivation, improve patient awareness about illness, provide accurate information, issues, facilitate the exchange of ideas,

frame and reframe health-related questions, and ultimately improve patient outcomes across health systems. Table 1 shows the analysis of ethical issues during information exchange and interaction. These are related to integration of two opposed fields: medicine with values of privacy, confidentiality, interpersonal and one-to-one interactions and the field of social media, with a culture of sharing, openness, transparency and informality $[35,36]$. This raises concerns over regulations of user interaction and file sharing $[37,38]$.

\section{Discussion}

Jonas [21] made assumptions that dealings with the non-human world are ethically neutral, the entity (man) and his condition is constant in essence and cannot itself be object of "reshaping techne. Jonas' theory is a reformulation of Kant's categorical imperative, which Myskja [39] presents as: "Act so that the effects of your action are compatible with the permanence of genuine human life", and therefore, agents ought to ensure that the effects of their actions do not destroy the future "genuine human life". Therefore, to ensure "genuine human life", agents ought to protect the future humanity's autonomy, dignity, integrity 
and risk from vulnerability. Jonas theory [21] highlights three key components of "substantive responsibility", namely, "totality, continuity and the future".

\section{Individual and collective agency}

The Social Cognitive Theory (SCT) posits that learnt behavior occurs in a social context, with a dynamic and reciprocal interaction between the individual and their environment to enact a given behavior [24,25]. SCT adopts an agent perspective in which individual efficacy motivates individuals as producers of experiences and shapers of events.

\section{Ethical issues related to use of social media as platforms for information exchange}

The information communicated or shared on digital platforms may lead to loss of privacy as it may be visible to others [40], and may include words, photos and videos [2]. The data, however, may include patient-identifying information, such as likeness, reports discussed on ward rounds, or data shared with others in seeking opinions and consultations for patient care-related services [32,41].

Such use markedly improves the patients' understanding of their illnesses and offers opportunity and forum to provide expert opinions and interpretations to broader patient populations $[41,42]$.

Ethical issues may be related to justice. These digital platforms are cheaper compared to other modes of communication such as telephone, making it more possible for users to communicate [32], often with many users in a short time, such as in an emergency [32]. Users who share private or confidential thoughts risk causing harms through revealing confidential patient information, as postings have potential to portray unprofessional behaviors [43]. The potential harms include violation of patient/client privacy or posting of confidential information [43], which may lead to dismissal or censorship $[44,45]$.

\section{Ethical issues related to the technology itself}

Facebook and WhatsApp have interconnections that allow individuals to connect with each other digitally and have the freedom to create their identities within this system [46]. On Facebook and WhatsApp, one can have multiple identities. This may influence a user's behaviour, whereby a user can create a false identity and use this to send false messages. Anonymity could enable users to send anonymous messages in case of a problem that needs concealment of identity, for example, when they want to act as whistle-blowers [47-49]. Ethical issues may be related to transmission of photos and pictures that could be uploaded and shared with other users of other platforms such as Instagram, Facebook or Twitter [4], where data (photos) may be edited to obscure reality. Inability to always transmit anonymized information raises ethical concerns. There are additional challenges of data storage, data security and data safety, which further adds to risk of loss of privacy and confidentiality. When a message is sent from a device via instant messaging, the data contained is transmitted via commercial servers on the Internet, from where it is retrieved by the message recipient [14]. The unpredictable risk from hackers or other intrusive malware creates concern over security of confidential patient information. Harms may arise out of over-use. While increasing connectedness [50], fuse may disrupt critical activities such as lectures or 
patient care [51, 52]. Addiction manifests as over dependency. Spread of negative information (cyberbullying) may also occur [53]. Another ethical concern is need for local, institutional and national guidelines on which data may be shared and what media should be used, depending on sensitivity and security concerns related to the data [34]. Misuse of social media potentially damages the reputation of both individuals and the institutions they represent [54].

\section{Conclusion}

Communication between patients and health workers using WhatsApp and Facebook can enhance patient care through improving patients' understanding of and coping with their illness. Health workers have for long used social media to benefit patients and enhance professional Networks. However, use of social media presents potential risks and burdens to all users (patients, healthcare professionalsebee, educators and trainees) leading to ethical challenges related to the technology, user behaviors and nature of the user interactions on the social media.

\section{Abbreviations}

CoP Community of practice

ICT Information and Communications Technology

SCT Social Cognitive Theory

\section{Declarations}

\section{Acknowledgements}

The author is grateful to the Welch Library for access to the e-resources of Johns Hopkins University and to the manuscript peer reviewers for their constructive comments.

\section{Authors' contributions}

DKK conceived the idea, conducted the background reading and literature search, reviewed the literature and drafted the manuscript.

Ethics approval and consent to participate

Not applicable

Ethics approval and consent to participate

Not applicable

Consent for publication 
Not applicable

Availability of data and material

Not applicable

Competing interests

The author declares that he has no competing interests

Funding

The author did not receive specific funding for the writing of the manuscript

\section{References}

1. Kietzmann JH, Hermkens K, McCarthy IP, Silvestre BS. Social media? Get serious! Understanding the functional building blocks of social media. Bus Horizon2011; 54:241-51.

2. Lewism K, Reicher MA. Web Applications for Patient Communication. J Am Coll Radiol 2016;13: 1603-1607.

3. Drake TM, Claireaux HA, Khatri C, Chapman SJ. WhatsApp with patient data transmitted via instant messaging? Am J Surg 2016; 211:300-1

4. Merchant RM, Elmer S, Lurie N. Integrating Social Media into Emergency-Preparedness Efforts. NEJM. 2011; 365:289-91.

5. Kaplan AM, Haenlein M. Users of the world, unite! The challenges and opportunities of Social Media. Bus Horizon. 2010;53: 59-68.

6. Kennedy G, Gray K, Tse J. 'Net Generation' medical students: technological experiences of pre-clinical and clinical students. Med Teach. 2008; 30:10-6.

7. Giordano C, Giordano C. Health professions students' use of social media. J All Health.2011;40(2):78-81

8. Peck JL. Social media in nursing education: responsible integration for meaningful use. J Nurs Educ. 2014; 19:1-6

9. Zhu Y, Proctor R. Use of blogs, Twitter, and Facebook by UK PhD students for scholarly communication. Observatoria 2015; 29: 29-46

10. Grindrod K, Forgione A, Tsuyui RT, et al: Pharmacy 2.0: a scoping review of social media use in pharmacy. Res Social Adm Pharm. 2014;101:256-70.

11. Ventola CL. Social Media and Health Care Professionals: Benefits, Risks, and Best Practices. Pharmacy and Therapeutics 2014; 39: 491-9 
12. Veneroni L, Ferrari A, Acerra S, Massimino M, Clerici CA. Considerations on the use of WhatsApp in physician-patient communication and relationship. Recenti Prog Med 2015; 106: 331-6.

13. Von Muhlen M, Ohno-Machado L. Reviewing social media use by clinicians. J Am Med Inform Assoc.2012;19: 777-81

14. George DR, Rovniak LS, Kraschnewski JL. Dangers and opportunities for social media in medicine. Clin Obstet Gynecol. 2013;56: 453-62

15. Househ M. The use of social media in healthcare: organizational, clinical, and patient perspectives. Stud Health Technol Inform. 2013; 183:244-8.

16. Dizon DS, Graham D, Thompson MA, et al. Practical guidance: The use of social media in oncology practice. J Oncol Pract. 2012; 8:114-24

17. Lambert KM, Barry P, Stokes G. Risk management and legal issues with the use of social media in the healthcare setting. J Healthc Risk Manag. 2012; 31:41-7.

18. Gray K, Annabell L, Kennedy G. Medical students' use of Facebook to support learning: Insights from four case studies. Med Teach.2010;32:971-6

19. Farnan JM, Snyder SL, Worster BK, et al: Online medical professionalism: patient and public relationships: policy statement from the American College of Physicians and the Federation of State Medical Boards. Ann Intern Med.2013;158: 620-7.

20. Arksey H, O'Malley L. Scoping studies: towards a methodological framework. Int J Soc Res Methodol 2005;8:19-32.

21. Jonas H. 1984. The imperative of responsibility: In search for an ethics for the technological age. Chicago: University of Chicago Press.

22. Wenger, 1998. Communities of practice. Learning, meaning, and identity, Cambridge, UK: Cambridge University Press.

23. Wenger $\mathrm{E}, \mathrm{McDermott} \mathrm{R}$, Snyder 2002. Cultivating communities of practice. A guide to managing knowledge, Cambridge, MA: Harvard Business School Press

24. Bandura A. Social cognitive theory: an agentic perspective. Anu Rev Psychol. 2001; 52:1-26

25. Bandura A. Exercise of human agency through collective efficacy. American Sociology Society 2000; 9: 75-8.

26. Serrato MG: 'Watch-Think-Write' and Other Proven Strategies for Using Video in the Classroom. https://ww2.kqed.org/education/2016/08/23/watch-think-write-and-other-proven-strategies-forusing-video-in-the-classroom/ Accessed Oct 12, 208

27. George DR, Dreibelbis TD, Aumiller B. How we used two social media tools to enhance aspectsof active learning during lectures. Med Teach. 2013; 35:985-8.

28. George DR. "Friending Facebook?" A minicourse on the use of social media by health professionals.J Con Educ Health Profess. 2011; 31: 215-19

29. Lagu T, Kaufman EJ, Asch DA, Armstrong K. Content of weblogs written by health professionals.J Gen Intern Med. 2008; 23: 1642-6 
30. Fogelson NS, Rubin ZA, Ault KA. Beyond likes and tweets: an in-depth look at the physician social media landscape. Clin Obstet Gynecol. 2013;56:495-508

31. Grajales FJ, Sheps S, Ho K, et al. Social media: a review and tutorial of applications in medicine and health care. J Med Internet Res. 2014;16(2):e13.

32. Johnston MJ, King D, Arora S, et al. Smartphones let surgeons know WhatsApp: an analysis of communication in emergency surgical teams. Am J Surg 2015; 209:45-51.

33. Blumenfield $\mathrm{O}$, Brand R. Real time medical learning using the WhatsApp cellular network: a crosssectional study following the experience of a division's medical officers in the Israel Defense Forces Disaster and Military Medicine. The Journal of Prehospital, Trauma and Emergency Care 2016; 2:12

34. Cohen DA, Levy M, Cohen Castel O, Karkabi K. The influence of a professional physician network on clinical decision making. Patient Educ Couns.2013; 93:496-503.

35. Gunawardena CN, Lowe CA, Anderson T: Analysis of a global online debate and the development of an interaction analysis model for examining social construction of knowledge in computer conferencing. Educational Computing Research 1997; 17: 397-430

36. Cheston CC, Flickinger TE, Chisolm MS. Social Media Use in Medical Education: A Systematic Review. Acad Med. 2013; 88:893-901

37. Thompson LA, Dawson K, Ferdig R, Black EW, Boyer J, Coutts J, et al. The intersection of online social networking with medical professionalism. J Gen Intern Med.2008; 23:954-7.

38. Cartledge P, Miller M, Phillips B. The use of social-networking sites in medical education. Med Teach. 2013;35:847-57.

39. Myskja BK. The categorical imperative and the ethics of trust. Ethics and Information Technology 2008; $10: 213-20$

40. Brewster CT, King IC. WhatsApp: Improvementtool for surgical team communication. J Plast Reconstr Aesthet Surg. 2017; 70:705-6.

41. Hawkins CM, DeLao JA, Hung C. Social Media and the Patient Experience. J Am Coll Radio/ 2016; 13:1615-21.

42. Broughton DE, Schelble A, Cipolla K, Cho M, Franasiak J, Omurtag KR. Social mediain the REI clinic: what do patients want? J Assist Reprod Genet. 2018: 35: 1259- 63

43. Thompson LA, Black E, Duff WP, Black NP, Saliba H, Dawson K. Protected health information on social networking sites: Ethical and legal implications. J Med Internet Res. 2011; 13: e8.

44. Chretien KC, Kind T. Social media and clinical care: ethical, professional, and social implications. 2013;127: 1413-21

45. Papadakis MA, Teherani A, Banach MA, et al. Disciplinary action by medical boards and prior behavior in medical school. N Engl J Med. 2005;353: 2673-82

46. Ellison NB, Steinfield,C, Lampe C. The Benefits of Facebook-friends: Social capital and college students' use of online social network sites. Journal of Computer-Mediated Communication 2007; 12: $1143-68$ 
47. Using google drives backups. https://faq. whatsapp.com/en/android/28000019/?category=5245251 Accessed October 12, 2018

48. BBC News. Snapchat Hack Affects 4.6 Million Users - BBC News. Available at: http://www.bbc.co.uk/news/technology-25572661. Accessed October 12, 2018

49. Fairchild C: What WhatsApp Users Need to Know about Google Drive Backups https://www.nextgov.com/analytics-data/2018/08/what-whatsapp-users-need-know-about-googledrive-backups/150931/. Accessed October 12, 2018

50. Balakrishnan V, Raj RG. Exploring the relationship between urbanized Malaysian youth and their mobile phones: A quantitative approach. Telematics and Informatics 2012; 29: 263-72.

51. Walsh S, White K, Young R. Needing to connect: The effect of self and others on young people's involvement with their mobile phones. Australian Journal of Psychology 2010; 62, 194-203.

52. North D, Johnston K, Ophoff J: The use of mobile phones by South African university students. Issues in Informing Science and Information Technology 2014; 11: 115-38.

53. Runions KC, Bak M. Online moral disengagement, cyberbullying, and cyber-aggression. Cyberpsychol Behav Soc Netw. 2015;18:400-5.

54. Shore R, Halsey J, Shah K, et al. Report of the AMA Council on Ethical and Judicial Affairs: Professionalism in the Use of Social Media. J Clin Ethics. 2011; 22:165-72.

\section{Table}

Table 1: Ethical issues related to use of social media for educational and patient care-related purposes. 


\begin{tabular}{|c|c|c|}
\hline $\begin{array}{l}\text { Characteristic related } \\
\text { to use of social media }\end{array}$ & Ethical challenges & $\begin{array}{l}\text { Possible principle affected or } \\
\text { violated }\end{array}$ \\
\hline $\begin{array}{l}\text { Widely used media } \\
\text { Media acceptable to } \\
\text { some users } \\
\text { Provider performance } \\
\text { and student learning } \\
\text { enhanced }\end{array}$ & $\begin{array}{l}\text { Not all potential users know how to use } \\
\text { Issue of access to smart phones, internet or } \\
\text { data } \\
\text { Not all users know how to effectively } \\
\text { communicate on the media }\end{array}$ & $\begin{array}{l}\text { Autonomy } \\
\text { Beneficence } \\
\text { Distributive and procedural justice }\end{array}$ \\
\hline Data security & $\begin{array}{l}\text { Data security in case of lost or damaged } \\
\text { hardware or software } \\
\text { Data safety and Confidentiality } \\
\text { Privacy } \\
\text { Data stored may be lost or modified } \\
\text { Data theft or damage by hackers }\end{array}$ & $\begin{array}{l}\text { Beneficence if data is lost } \\
\text { (Non-maleficence if data is lost or } \\
\text { misused } \\
\text { Autonomy in being in control of } \\
\text { one's destiny }\end{array}$ \\
\hline $\begin{array}{l}\text { Use of shortcuts in } \\
\text { texts and emoticoms. } \\
\text { Use of slang } \\
\text { Use of acronyms, } \\
\text { abbreviations and } \\
\text { wrong cases }\end{array}$ & $\begin{array}{l}\text { Faults in data transmission or incorrect data } \\
\text { transmitted } \\
\text { Data may be misunderstood or misinterpreted } \\
\text { by recipients } \\
\text { Data privacy and confidentiality for intended } \\
\text { recipients }\end{array}$ & $\begin{array}{l}\text { Beneficence to in } \\
\text { Non-maleficence } \\
\text { Distributive and procedural justice } \\
\text { Autonomy }\end{array}$ \\
\hline $\begin{array}{l}\text { Multiple hidden user } \\
\text { profiles }\end{array}$ & $\begin{array}{l}\text { Loss of trust in face-less communications } \\
\text { Loss of personal interaction } \\
\text { Loss of proximity } \\
\text { Loss of co-presence } \\
\text { Ability to communicate anonymously as whistle } \\
\text { blowers }\end{array}$ & $\begin{array}{l}\text { Beneficence } \\
\text { Non-maleficence } \\
\text { Distributive and procedural justice } \\
\text { Autonomy and informed consent }\end{array}$ \\
\hline $\begin{array}{l}\text { Regulations or } \\
\text { guidelines on using } \\
\text { the social media }\end{array}$ & $\begin{array}{l}\text { Abuse such as cyberbullying } \\
\text { Loss of confidentiality } \\
\text { Loss of privacy } \\
\text { Distraction of users with useless information; } \\
\text { Issue of quality } \\
\text { Inability to regulate user behaviors }\end{array}$ & $\begin{array}{l}\text { Beneficence } \\
\text { Non-maleficence } \\
\text { Autonomy and informed consent } \\
\text { Distributive justice }\end{array}$ \\
\hline $\begin{array}{l}\text { Software or hardware } \\
\text { or } \\
\text { connectivity }\end{array}$ & $\begin{array}{l}\text { Disparity in access } \\
\text { Inequitable resource allocation } \\
\text { Need for updates }\end{array}$ & $\begin{array}{l}\text { Beneficence } \\
\text { Procedural and Distributive } \\
\text { Justice (from resource allocation, } \\
\text { cost and access) }\end{array}$ \\
\hline $\begin{array}{l}\text { Stakeholders } \\
\text { preferences } \\
\text { needs }\end{array}$ & $\begin{array}{l}\text { Stakeholders preferences not sought or } \\
\text { respected regarding whether, how, when and } \\
\text { which data to transmit }\end{array}$ & $\begin{array}{l}\text { Autonomy and informed consent } \\
\text { Distributive and procedural justice } \\
\text { Beneficence }\end{array}$ \\
\hline $\begin{array}{l}\text { Effectiveness } \\
\text { educational tools }\end{array}$ & $\begin{array}{l}\text { Effective as educational tools for individual or } \\
\text { group feedback } \\
\text { Media may be suitable for learning styles of } \\
\text { some students } \\
\text { Offer collaborative and social learning } \\
\text { Anonymous data sources } \\
\text { Typed errors and unknown slangs or shortcuts } \\
\text { and emoticoms } \\
\text { Users identifiable if user name is known } \\
\text { Messages displayed in the order in which they } \\
\text { are posted. } \\
\text { Loss of trust, co-presence and proximity } \\
\text { Impersonal communication }\end{array}$ & $\begin{array}{l}\text { Beneficence } \\
\text { Distributive and procedural justice } \\
\text { Autonomy and informed consent } \\
\text { for some users }\end{array}$ \\
\hline User ser behaviors & Dependence and Addiction & Non-maleficence \\
\hline
\end{tabular}

Page 10/10 